\title{
PENGARUH LIMBAH CAIR PENGOLAHAN HASIL PRODUK TAMBANG (EMAS) TERHADAP KUALITAS AIR SUNGAI GAJAH WONG DI KECAMATAN KOTAGEDE DAERAH ISTIMEWA YOGYAKARTA
}

\author{
Primanda Kiky Widyaputra*, Dwi Herniti*, Ika Arsi Anafiati* \\ *Teknik Pertambangan, Institut Teknologi Yogyakarta
}

\begin{abstract}
INTISARI
Sungai Gajah Wong adalah salah satu sungai yang melintasi Kota Yogyakarta, salah satunya melintasi Kecamatan Kotagede yang merupakan satu kawasan sentra kerajinan emas. Penurunan kualitas air Sungai Gajah Wong yang melintasi kecamatan tersebut dapat terjadi apabila terjadi pencemaran berupa limbah cair pengolahan emas. Pencemaran tersebut dapat mengakibatkan terjadinya perubahan kondisi fisik dan kimia yang terdapat pada air. Dengan kondisi tersebut, maka perlu dilakukan penelitian tentang pengaruh limbah cair pengolahan hasil produk tambang emas terhadap kualitas air Sungai Gajah Wong. Adapun tujuan dari penelitian ini adalah mengetahui seberapa besar pengaruh limbah cair pengolahan produk hasil tambang emasterhadap kualitas air Sungai Gajah Wong di Kecamatan Kotagede, DIY. Metode yang digunakan dalam penelitian ini adalah metode survei dengan teknik pengambilan sampel secara purposive sampling. Parameter yang akan diteliti dalam penelitian ini adalah parameter fisika dan kimia. Parameter fisika untuk uji kualitas air sungai di daerah penelitian terdiri dari $\mathrm{pH}$, suhu, bau, kekeruhan, warna, dan total solid suspended (TSS). Parameter kimia untuk uji kualitas daerah penelitian adalah Raksa (Hg). Pengujian terhadap parameter fisika dan kimia dilakukan di laboratorium. Pengambilan sampel air sungai mengacu pada SNI 062412-1991 tentang metode pengambilan contoh air.Berdasarkan hasil penelitian menunjukkan bahwa dari adanya pengolahan emas di sekitar Sungai Gajah Wong dijumpai parameter $\mathrm{Hg}$ pada hasil rata-rata 0,006 $\mathrm{mg} / \mathrm{L}$.

Katakunci: Emas, Sungai, Kualitas Air
\end{abstract}

\section{THE INFLUENCE OF LIQUID WASTE PROCESSING OF MININGPRODUCTS(GOLD) ON THE WATER QUALITY OF GAJAH WONG RIVER IN KOTAGEDE DISTRICT DAERAH ISTIMEWA YOGYAKARTA}

\begin{abstract}
Gajah Wong River is one of the river that cross Yogyakarta City, especially in Kecamatan Kotagede which is one of the central area of gold craft. The decline of water quality of the Gajah Wong River may occur if there is pollution of liquid waste from gold processing. The pollution may result changes in the physical and chemical condition found in water. Due to the condition, the investigation of the influence of liquid waste processing is needed. Therefore the objective of this research is to analyze the influence of liquid waste processing gold mine products on the quality of the Gajah Wong River.Methods used in this research is descriptive analysis using purposive sampling as sampling methods, with parameter including physical and chemistry.Physical parameters consist of ph, temperature, odor, and total solid suspended (TSS).The chemistry parameters is mercury $(\mathrm{Hg})$.. The sample collection the waters refers to SNI 06-2412-1991. Based on the result indicates that the presence of the gold processing effect in the vicinity of the river with $\mathrm{Hg}$ as parameter is on average $0,006 \mathrm{mg} / \mathrm{l}$.
\end{abstract}

Keywords: Gold, River, Water Quality 


\section{A. PENDAHULUAN}

Sungai Gajah Wong adalah salah satu sungai yang melintasi Kota Yogyakarta, dengan bagian hulu berada di Kabupaten Sleman, sedangkan bagian hilir berada di Kabupaten Bantul. Sungai Gajah Wong merupakan salah satu ekosistem aquatik yang keberadaannya sangat dipengaruhi oleh aktivitas atau kegiatan di sekitarnya. Fungsi penting ini menjadi salah satu alasan pentingnya menjaga kualitas air sungai dari pencemaran yang dapat menjadi sumber berbagai penyakit. Adanya masukan bahan pencemar ke sungai mengakibatkan penurunan kualitas air. Bahan pencemar yang masuk tersebut berasal dari pembuangan limbah kegiatan domestik maupun industri yang akan mengakibatkan meningkatnya pencemaran di sungai. Penurunan tersebut dapat diakibatkan oleh berbagai masukan limbah yang berasal dari limbah domestik rumah tangga maupun domestik, yang dapat berasal dari buangan industri penyamakan kulit, bengkel dan cuci mobil, serta pengolahan dan pelapisan emas dan perak (Purba, 2008).Akibat yang ditimbulkan antara lain menurunnya kualitas air dan pendangkalan sungai.

Kecamatan Kotagede sebagai salah satu sentra kerajinan perak merupakan salah satu pusat kegiatan pengolahan hasil produk tambang, terutama perak dan emas. Penurunan kualitas air Sungai Gajah Wong yang melintasi kecamatan tersebut dapat terjadi apabila terjadi pencemaran. Pencemar berupa limbah cair pengolahan perak dan emas yang masuk ke dalam sungai dapat mengakibatkan terjadinya perubahan kondisi fisik dan kimia yang terdapat pada air. Kondisi tersebut dapat menurunkan kualitas lingkungan serta penurunan keanekaragaman biota sungai. Berdasarkan latar belakang dan permasalahan yang dijumpai, maka dirumuskan tujuan penelitian yaitu mengidentifikasi besar limbah cair pengolahan produk hasil tambang (emas) pada Sungai Gajah Wong di Kecamatan Kotagede, DIY.

\section{B. TINJAUAN PUSTAKA \\ 1. Emas}

Emas adalah unsur kimia dalam tabel periodik yang memiliki simbol $\mathrm{Au}$ dan nomor atom 79, merupakan sebuah logam transisi (trivalen dan univalen) yangmengkilap, berat, "malleable", dan "ductile". Emas tidak mudah bereaksi dengan zat kimia lainnya. Logam emas banyak terdapat di bebatuan dan pada deposit alluvial. Emas melebur dalam bentuk cair pada suhu sekitar $1000^{\circ} \mathrm{C}$. Emas ditemukan di deposit-deposit alluvial dan sering dipisahkan dari bebatuan dan mineral-mineral lainnya dengan proses penambangan.

\section{Pengolahan Emas}

Pengolahan emas dapat dilakukan dengan dua cara yaitu dengan amalgamasi dan sianida. Amalgamasi adalah proses penyelaputan partikel emas oleh air raksa dan membentuk 
amalgam $(\mathrm{Au}-\mathrm{Hg})$. Amalgam masih merupakan proses ekstraksi emas yang paling sederhana dan murah, akan tetapi proses efektif untuk bijih emas yang berkadar tinggi dan mempunyai ukuran butir kasar (> 74 mikron) dan dalam membentuk emas murni yang bebas (free native gold). Proses amalgamasi merupakan proses kimia fisika, apabila amalgamnya dipanaskan, maka akan terurai menjadi elemen-elemen yaitu air raksa dan bullion emas. Amalgam dapat terurai dengan pemanasan di dalam sebuah retort, air raksanya akan menguap dan dapat diperoleh kembali dari kondensasi uap air raksa tersebut. Sementara Au-Ag tetap tertinggal di dalam retort sebagai logam.

$$
\text { Pengolahan emas dengan }
$$

sianidasi emas (juga dikenal sebagai proses sianida atau proses MacArthurForrest) adalah teknik metalurgi untuk mengekstraksi emas dari bijih kadar rendah dengan mengubah emas ke kompleks koordinasi yang larut dalam air (Anonim, 2011). Sianidasi adalah proses yang paling umum digunakan untuk ekstraksi emas. Produksi reagen untuk pengolahan mineral untuk memulihkan emas, tembaga, seng dan perak mewakili sekitar $13 \%$ dari konsumsi sianida secara global, dengan $87 \%$ sisa sianida yang digunakan dalam proses industri lainnya seperti plastik, perekat, dan pestisida. Karena sifat yang sangat beracun dari sianida, proses ini kontroversial dan penggunaannya dilarang di sejumlah negara dan wilayah.

\section{Pengaruh Limbah Cair Pengolahan Emas dan Perak Terhadap Kualitas Air}

Kualitas air berdasarkan definisi dari SNI 03-7016-2004 adalah sifatsifat air yang ditunjukkan dengan nilai dan/atau kadar makhluk hidup, zat, energi, termasuk bahan pencemar, dan/atau komponen lain yang ada dan/atau terkandung di dalam air. Kualitas air sungai dipengaruhi oleh kualitas pasokan air yang berasal dari daerah tangkapan sedangkan kualitas pasokan air dari daerah tangkapan berkaitan dengan aktivitas manusia yang ada di dalamnya. Aktivitas manusia, termasuk pertambangan, dapat berpengaruh pada kualitas air sungai, sebagaimana dalam penelitian yang dilakukan oleh Subanri (2008), dalam penelitian ini dikaji beban dan dampak yang diakibatkan oleh pencemaran limbah merkuri $(\mathrm{Hg})$ dari penambangan serta kadar $\mathrm{Hg}$ air sungai. Limbah cair kegiatan pertambangan bijih emas dan atau tembaga terdiri dari: 1) Limbah cair kegiatan penambangan bijih emas yaitu air yang terkena dampak kegiatan penambangan bijih emas sehingga kualitasnya berubah dan perubahan tersebut terkait langsung dengan kegiatan penambangan bijih emas; 2) Limbah cair kegiatan pengolahan bijih emas yang dibuang ke badan air; serta 3) Limbah cair bagi kegiatan paska penutupan tambang.Kegiatan industri yang pengolahannya menggunakan bahan logam berat dan menghasilkan limbah buang tanpa pengolahan 
terdahulu, maka akan menimbulkan pencemaran lingkungan.

Mercuri sebagai bahan pemisah emas dengan mineral lainnya dapat menimbulkan dampak pencemaran lingkungan terutama pada kualitas air sungai, yaitu mengandung logam berat yang berbahaya bagi kehidupan ekosistem sungai (Agus, dkk., 2005)

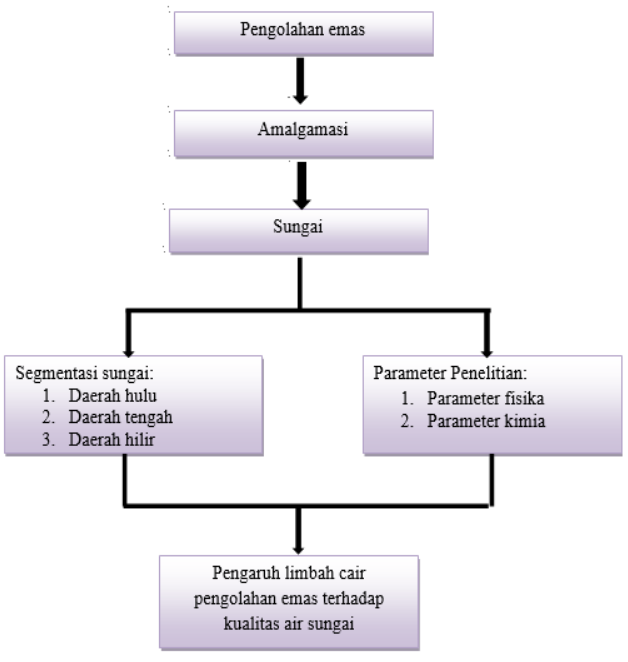

Gambar 1. Kerangka Pemikiran

\section{METODE PENELITIAN}

\section{Lokasi Penelitian}

Penelitian ini dilaksanakan di Kecamatan Kotagede Daerah Istimewa Yogyakarta yaitu di Sungai Gajah Wong. Letak geografis Kotagede yaitu antara 1100 24'19" - 1100 27'53" BT dan 70 15'35" - 70 49'35' LS.

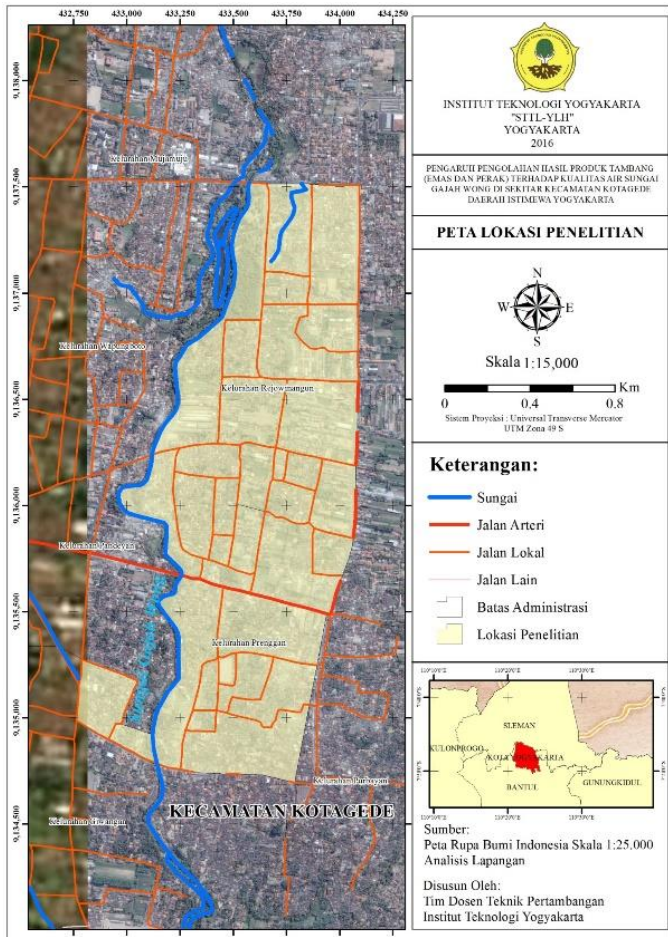

Gambar 2. Peta Lokasi Penelitian

\section{Tahapan Penelitian}

Penelitian ini dilakukan melalui beberapa tahapan sebagai berikut:

a. Tahap Pra-Survey

1. Pengorganisasian alat-alat penelitian dan alat-alat laboratorium yang akan digunakan.

2. Pengumpulan data sekunder berupa data iklim.

3. Pembuatan lembar pengamatan untuk pengumpulan data lapangan

4. Orientasi lapangan untuk memahami kondisi daerah penelitian.

5. Penentuan lokasi pengambilan sampel berdasarkan zonasi peta 
satuan lahan yaitu daerah hulu, tengah dan hilir.

b. Tahap Penelitian Lapangan

1. Pengambilan sampel di lapangan untuk uji laboratorium.

2. Pengamatan kondisi lokasi sekitar pengambilan sampel.

c. Tahap Penyelesaian

1. Uji Laboratorium

2. Pengolahan data hasil pengukuran uji laboratorium di sajikan dalam bentuk tabel dan grafik.

3. Penulisan atau narasi sebagai interprestasi dari hasil analisis data untuk penyusunan laporan.

\section{Metode Pengambilan Data}

Metode yang digunakan dalam penelitian ini adalah metode analisis deskriptif dengan pengambilan sampel secara secara purposive sampling. Parameter yang diteliti dalam penelitian ini adalah parameter fisika dan kimia. Parameter fisika untuk uji kualitas air sungai di daerah penelitian terdiri dari $\mathrm{pH}$, suhu, bau, kekeruhan, warna, dan Total Solid Suspended (TSS). Parameter kimia untuk uji kualitas daerah penelitian adalah Raksa ( $\mathrm{Hg}$ ). Pengujian terhadap parameter fisika dan kimia akan dilakukan di laboratorium.

Pengambilan sampel air sungai mengacu pada SNI 06-2412-1991 tentang metode pengambilan contoh air. Pengambilan sampel air sungai dengan debit kurang dari $5 \mathrm{~m}^{3} /$ detik, contoh diambil pada satu titik di tengah sungai pada $0,5 \mathrm{x}$ kedalaman dari permukaan air, jika sungai dengan debit antara 5 $150 \mathrm{~m}^{3} /$ detik, contoh diambil pada dua titik masing-masing pada jarak $1 / 3$ dan 2/3 lebar sungai pada $0,5 \times$ kedalaman dari permukaan air. Pengambilan sampel akan dilakukan dengan dua kali pengulangan.

\section{Metode Analisis Data}

Analisis kualitas air dilakukan di laboratorium yang meliputi analisis fisik, kimia terhadap air yang diambil dari sungai guna mengukur kandungan unsur-unsur pencemar sebagaimana yang sudah dipilih sebagai parameter pencemaran dalam penelitian ini sesuai dengan Peraturan Gubernur Daerah Istimewa Yogyakarta Nomor 7 Tahun 2010 Tentang Baku Mutu Limbah Cair Bagi Kegiatan Industri, Pelayanan Kesehatan, dan Jasa Pariwisata. 


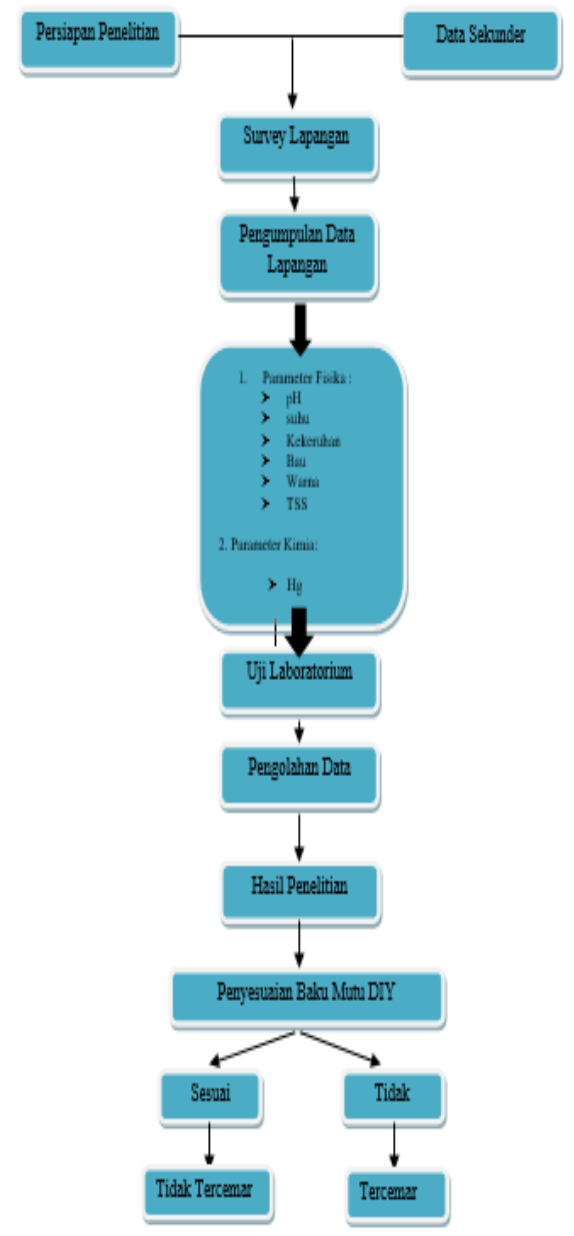

Gambar 2. Alur Metode Penelitian

\section{HASIL DAN PEMBAHASAN}

\section{Pengamatan Kondisi Lingkungan}

Kotagede merupakan sentra kerajinan perak di Yogyakarta. Kerajinan perak sendiri merupakan budaya turun temurun. Pada awalnya kerajinan di Kotagede berupa emas, perak dan tembaga. Namun seiring waktu, kerajinan peraklah yang paling diminati. Kerajinan perak Kotagede memiliki ciri khas tersendiri, yakni tetap dipertahankannya proses pembuatan barang kerajinan secara manual. Berdasarkan data Dinas
Perindustrian, Perdagangan, dan Koperasi Kota Yogyakarta, salah satu sektor industri yang menyumbang devisa negara melalui kegiatan ekspor. Industri kerajinan perak ini pada tahun 2011 memiliki volume industri sekitar 1,34 juta $\mathrm{kg}$ pertahun dengan nilai 400 juta rupiah. Selain kerajinan perak juga terdapat kerajinan emas dengan jenis produk yang dihasilkan berupa perhiasan (giwang, gelang dan kalung) dengan kadar emas sekitar 85\% (Sahputra, 2012). Industri perak dan emas di Kecamatan Kotagede tersebar di 3 kelas jalan, yakni jalan arteri, jalan kolektor, dan jalan lokal.

Sebagian besar industri terdapat di kelas jalan kolektor yakni 31 industri (39.24 \%) yang berada di Jalan Mandorakan, Jalan Ngeksigondo, dan Jalan Kemasan yang meiniliki 21 titik industri dan total 31 industri di Jalan kolektor. Sebanyak 19 industri terdapat di jalan lokal dan 29 industri di jalan arteri. Persebaran industri tersebar di jalan arteri seperti Jalan Tegalgendu, Jalan Mandorakan dan Jalan Ngeksigondo karena terhubung dengan Ringroad Selatan dan Ringroad Timur, maupun jalan kolektor seperti Jalan Kemasan dan Jalan Nyi Pembayun maupun Jalan Kolektor di Kecamatan Kotagede seperti Jalan Purbayan yang menjadi akses lalu lintas masuk dan keluar Kecamatan Kotagede.

Di Kelurahan Rejowinangun, pemukiman warga relatif bersih, padat, namun tidak terlihat sampah berserakan, serta terdapat IPAL komunal. Air yang mengalir cukup deras dikarenakan 
kedalaman sungai yang dangkal, sehingga tidak ada sampah yang tercecer di pinggir sungai.

Lokasi Jembatan Tegalgendu, terdapat 2 industri perak dan emas yang berada di barat jembatan, yaitu Narti's Silver dan Ansor's Silver yang letaknya sangat berdekatan. Sedangkan di timur jembatan terdapat 1 industri yaitu HS silver. Sampel air diambil tepat di selatan Jembatan Tegal Gendu yang mana merupakan titik terdekat dengan sentra industri. Kondisi sungai cukup kotor, masih ada sampah yang tersangkut di tiang jembatan dan limpahan sampah dari daerah hulu. Di lokasi Kelurahan Mrican, terdapat sampah yang berada di antara kedua sisi sungai, namun volumenya tidak menghalangi laju air. Di utara titik pengambilan sampel, terdapat aktivitas tambang pasir yang dilakukan oleh swadaya warga.

\section{Analisis Hasil Sampling}

Berdasarkan persebaran dan lokasi industri tersebut, sampel pengamatan dan pengukuran ditetapkan di tiga lokasi, yaitu di Kelurahan Rejowinangun, Kelurahan Jembatan Tegal Gendu, dan Kelurahan Mrican. Berdasarkan hasil penelitian yang dilakukan di sungai Gajah Wong pada 3 titik sampling yaitu di Kelurahan Rejowinangun, Kelurahan Jembatan Tegal Gendu, dan Kelurahan Mrican terlihat bahwa parameter yang diteliti semua berada dibawah ambang batas Baku Mutu Limbah DIY menurut Perda DIY No 7 tahun 2016.

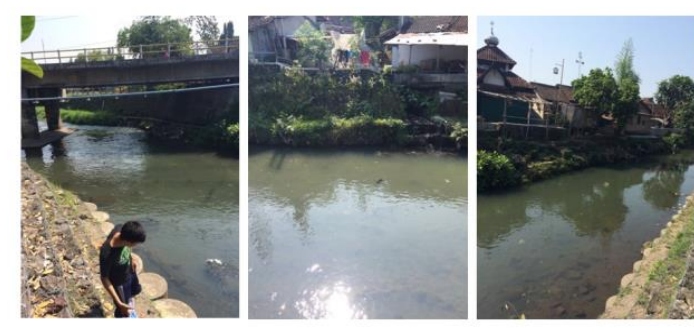

Gambar 3. Situasi Lokasi Penelitian

Parameter $\mathrm{pH}$ dan Suhu pada Standar Baku Mutu Limbah adalah 6-9 dan \pm 30 terhadap suhu udara, pada hasil penelitian menunjukkan $\mathrm{pH} 7$ dan suhu rata-rata pada tiga titik sampling \pm 250, artinya semua dibawah baku mutu limbah yang disarankan. Parameter $\mathrm{Hg}$ pada hasil rata-rata $<0,006 \mu \mathrm{g} / \mathrm{L}$, menurut baku mutu limbah adalah 0,002 $\mathrm{mg} / \mathrm{L}$ berdasarkan hasil tersebut terdapat indikasi pencemaran raksa akibat pengolahan industri emas di sungai Gajah Wong.

Parameter TSS menurut Baku Mutunya adalah sebesar $20.00 \mathrm{mg} / \mathrm{L}$ sedangkan hasil penelitian sebesar 2.00 $\mathrm{mg} / \mathrm{L}$, zat yang tersuspensi biasanya terdiri dari zat organik dan anorganik, secara fisika zat ini sebagai penyebab kekeruhan pada air, ini artinya bahwa tidak ada padatan yang menyebabkan air sungai Gajah Wong menjadi keruh.Kualitas air sungai Gajah Wong menurut hasil penelitian masih dibawah baku mutu. Penelitian menunjukkan bahwa dari parameter yang diteliti,tidak ditemukan limbah hasil pengolahan emas yang mencemari sungai tersebut.

Terdapat beberapa usaha untuk menanggulangi pencemaran, yaitu penanggulangan secara non-teknis dan 
secara teknis (Warlina, 2004). Penanggulangan secara non-teknis yaitu suatu usaha untuk mengurangi pencemaran lingkungan dengan cara menciptakan peraturan perundangan yang dapat merencanakan, mengatur dan mengawasi segala macam bentuk kegiatan industri dan teknologi sehingga tidak terjadi pencemaran.

Tabel 1. Hasil Uji Sampel Air Sungai Gajah Wong

\begin{tabular}{|l|c|r|l|r|}
\hline No & Parameter & $\begin{array}{l}\text { Standar } \\
\text { Baku } \\
\text { Mutu }\end{array}$ & $\begin{array}{l}\text { Nilai Uji } \\
\text { Sampel } \\
\text { Air } \\
\text { (rata- } \\
\text { rata) }\end{array}$ & Satuan \\
\hline 1 & $\mathrm{pH}$ & $6-9$ & 7 & \\
\hline 2 & $\mathrm{Suhu}$ & $\begin{array}{r} \pm 3^{\circ} \mathrm{C} \\
\text { dari suhu } \\
\text { udara }\end{array}$ & 25 & ${ }^{\circ} \mathrm{C}$ \\
\hline 3 & $\mathrm{TSS}$ & 20.00 & 2.00 & $\mathrm{mg} / \mathrm{L}$ \\
\hline 4 & $\mathrm{Hg}$ & 0,002 & 0,006 & $\mathrm{mg} / \mathrm{L}$ \\
\hline
\end{tabular}

\section{E. KESIMPULAN DAN SARAN}

\section{Kesimpulan}

Hasil penelitian menunjukkan bahwa semua parameter yang diuji berada di bawah baku mutu limbah DIY, artinya tidak terjadi pencemaran di Sungai Gajah Wong. Hasil penelitian tidak melebihi baku mutu, akan tetapi tetap harus dijaga agar kedepannya tidak melebihi baku mutu. Mengingat jumlah penduduk yang semakin bertambah, munculnya industri baru sehingga dapat menambah beban pencemar untuk masa yang akan datang, sehingga perlu ada pencegahan sebelum terjadi pencemaran.

\section{Saran}

Berdasarkan hasil penelitian dan pengamatan, disarankan beberapa hal sebagai berikut:

1. Semua industri perak maupun emas yang ada di sekitar Sungai Gajah Wong sebaiknya mempunyai IPAL untuk mengelola limbah cairnya untuk mencegah terjadinya pencemaran.

2. Harus ada pengawasan bersama terhadap limbah yang keluar baik oleh perusahaan maupun masyarakat sekitar industri yang berada disekitar Sungai Gajah Wong.

3. Mempertahankan kondisi lingkungan agar tetap terjaga dengan baik sehingga sungai Gajah Wong dapat berfungsi sesuai dengan peruntukannya.

\section{DAFTAR PUSTAKA}

Agus, C., Sukandarrumidi, Wintolo, D. 2005. Dampak Limbah Cair Hasil Pengolahan Emas TerhadapKualitasair Sungai danCara Mengurangi Dampak Dengan Menggunakan Zeolit: Studi Kasus Penambangan Emas Tradisional Di Desa Jendi Kecamatan Selogiri Kabupaten Wonogiri Provinsi Jawa Tengah

Asih, E.W., 2015, Analisis Produktivitas Pada Proses Penyepuhan Dengan Metode 
Green Productivity, Seminar

Nasional IENACO.

Sahputra, Choirudin. 2012. Pola

Keruangan Industri Kerajinan

Perak Kotagede Yogyakarta.

Skripsi. Universitas Indonesia

Sekarwati, N., 2014, Dampak

Logam Berat $\mathrm{Cu}$ (Tembaga)

Dan Ag (Perak)Pada Limbah

Cair Industri Perak Terhadap

Kualitas Air Sumur Dan

Kesehatan Masyarakat Serta

Upaya Pengendaliannya Di

Kota Gede Yogyakarta, Tesis.

Program Pascasarjana

Program Studi Ilmu

Lingkungan Universitas

Sebelas Maret.

Subanri. 2008. Kajian Beban

Pencemaran Merkuri (Hg)

Terhadap Air Sungai

Menyuke Dan Gangguan

Kesehatan Pada Penambang

Sebagai Akibat Penambangan

Emas Tanpa Izin (Peti)

Dikecamatan Menyuke

Kabupaten Landak

Kalimantan Barat. Tesis.

Program PascaSarjana

Magister Kesehatan

Lingkungan Universitas

Diponegoro Semarang

Warlina L. 2004. Pencemaran air:

Sumber, Dampak, Dan

Penanggulangannya.Paper.

Bogor : Sekolah Pasca

Sarjana Institut Pertanian

Bogor 
